\title{
Analyzing Predictive Role of Pre-Service Teachers' Occupational Anxiety Level on Positive Emotions
}

\author{
Neslin İhtiyaroğlu ${ }^{1, *}$ \\ ${ }^{1}$ Faculty of Education, Kırıkkale University, Kırıkkale, Turkey \\ *Correspondence: Faculty of Education, Kırıkkale University, Kırıkkale, Turkey. E-mail: neslin52@gmail.com
}

This study was presented as oral presentation in at $27^{\text {th }}$ International Congress on Educational Sciences (ICES/UEBK-2018) hold on 18-22 April, 2018 in Antalya.

Received: September 18, 2018

Accepted: November 17, $2018 \quad$ Online Published: February 19, 2019

doi:10.5430/wje.v9n1p162

URL: https://doi.org/10.5430/wje.v9n1p162

\begin{abstract}
The objective of this study is to examine the predictive role of pre-service teachers' professional anxiety on positive emotions. The relational screening model was adopted in the study. 484 pre-service teachers were selected from the Faculty of Education in Kırıkkale University with stratified sampling method for sample. Occupational Anxiety Scale and Dispositional Positive Emotion Scales were applied to sample group. Correlation and multiple regression analysis were used to analyze the data. Correlation analysis revealed that the relations between contentment and occupational exam centered anxiety and socio-economic centered anxiety have the highest scores, whereas the relations between compassion and socio-economic centered anxiety and school management centered anxiety have the lowest scores. Results of multiple regression analysis indicated that occupational exam centered anxiety and socio-economic centered anxiety are significant predictors of positive emotions but job oriented anxiety, interaction with students centered anxiety, colleagues and students' parents centered anxiety, self-development centered anxiety, adaptation self-development centered anxiety and school management centered anxiety isn't a predictor for positive emotions. Suggestions for decreasing the pre-service teachers' occupational anxiety level were presented at the end of the study.
\end{abstract}

Keywords: occupational anxiety, positive emotions, pre-service teachers

\section{Introduction}

One of the most important factors that affect lives and behaviors of the individuals is emotions. Emotions have a power which direct many important decisions, relationships and even the individuals' reflex behaviors in daily life. For that reason, it is quite important to raise individuals' awareness about understanding and directing their own emotions.

Emotion may be described as a physiological and cognitive state which occurs as a result of stimulation (Schachter \& Singer, 1962); reactions which activate individuals and direct their priorities and plans (Oatley \& Jenkins, 1996); impacts which shape individuals' behaviors, actions, activities and even surviving processes (Kervanc1, 2008); intense sentiments directed towards other individuals or objects (Frijda, 2008). When the research by Kleinginna and Kleinginna (1981) on emotions is examined, they reached 92 different definitions about the concept of emotion. The reason for this is that the concept of emotion cannot be expressed in a single definition as it affects and is affected by many factors.

Emotions serve for resolution of conflicts between what they do or feel and events that surround them; between what they do and what they want to do in fact; between what they do and what they say or know; between what they do and what must be the most appropriate and most reasonable (Frijda, 2008). When exhibiting the differences between moods, Robbins and Jude (2013) described the features of emotions as follows: Emotions occur as a result of a certain incident, are short termed, quite high in number but each have many unique features, they occur in accompaniment of clear facial expressions and they are action oriented. Psychoevolutionary Theory of Basic Emotions developed by Plutchik (2001) are based on ten basic postulates in relation to emotions: 
- Animals and Humans: The concept of emotion is applicable to all evolutionary levels and applies to all animals including humans.

- Evolutionary History: Emotions have an evolutionary history and have evolved various forms of expression in different species.

- Survival Issues: Emotions served an adaptive role in helping organisms deal with key survival issues posed by the environment.

- Prototype Patterns: Despite different forms of expression of emotions in different species, there are certain common elements, or prototype patterns, that can be identified.

- Basic Emotions: There is a small number of basic, primary, or prototype emotions.

- Combinations: All other emotions are mixed or derivative states; that is, they occur as combinations, mixtures, or compounds of the primary emotions.

- Hypothetical Constructs: Primary emotions are hypothetical constructs or idealized states whose properties and characteristics can only be inferred from various kinds of evidence.

- Opposites: Primary emotions can be conceptualized in terms of pairs of polar opposites.

- Similarity: All emotions vary in their degree of similarity to one another.

- Intensity: Each emotion can exist in varying degrees of intensity or levels of arousal.

Based on these postulates, it can be said that emotions exist in all living things, they may have similar features despite differing according to organisms, they support survival process of living things, there are a few primary emotions and all other emotions are derived from such primary emotions, each emotion may have a similar or opposite and its intensity or severity varies according to circumstances.

No consensus is achieved by researchers in relation to classification of primary emotions and each researcher classified primary emotions in different ways. In his classification, Plutchik (1980) divided primary emotions into eight as emotions which help the organism adapt to the environment and he gained recognition in the literature with this classification. As seen in Figure 1, these eight emotions are joy, trust, fear, surprise, sadness, disgust, anger and anticipation.

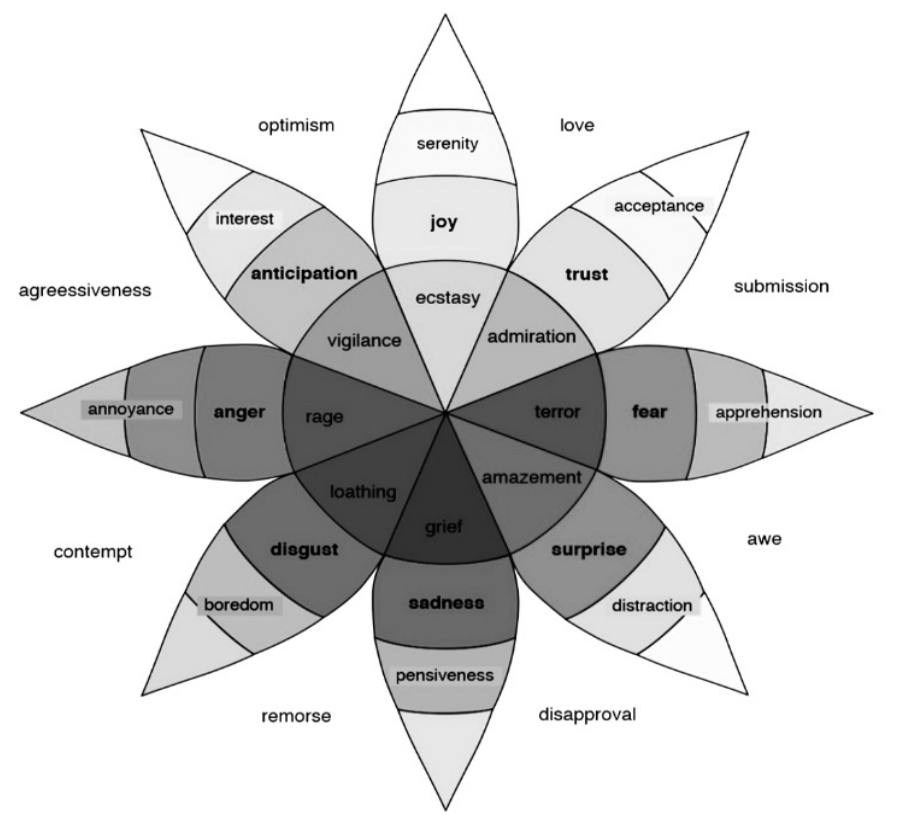

Figure 1. Plutchik's Wheel of Emotions 
In Plutchik's wheel of emotions, each emotion has a mission for individual's sustaining vital features. Anger allows struggling with problems; anticipation helps going towards future and making plans; joy reminds individuals what is important; trust establishes connections among individuals; fear protects individuals from dangers; surprise allows individuals to focus on new situations; sadness brings individuals closer to whom they love; disgust keeps individuals away from unhealthy things (Freedman, 2007). While emotions which are close to each other show similar features; opposing emotions express contrast (Tuna, 2011). While loathing and disgust or terror and fear have similar features; loathing and admiration or grief and ecstasy are contrasting emotions. Furthermore, primary emotions unite and create other emotions. For example, joy and trust create love; disgust and sadness create remorse. There are also different classifications about primary emotions. Gray (1982) listed primary emotions as anger, terror, apprehension and joy and Oatley and Johnson-Laird (1987) listed primary emotions as anger, loathing, apprehension, joy and sadness.

Emotions may also be analyzed as positive and negative emotions. Positive emotions such as joy and trust express positive evaluation and senses; negative emotions such as anger and disgust express negative evaluation and senses. An, Ji, Marks and Zhang (2017) analyzed positive and negative meanings of emotions according to countries. As seen in Figure 2, it was exhibited that negative aspects of emotions such as fear, sadness, disgust and anger are stronger than positive aspects.

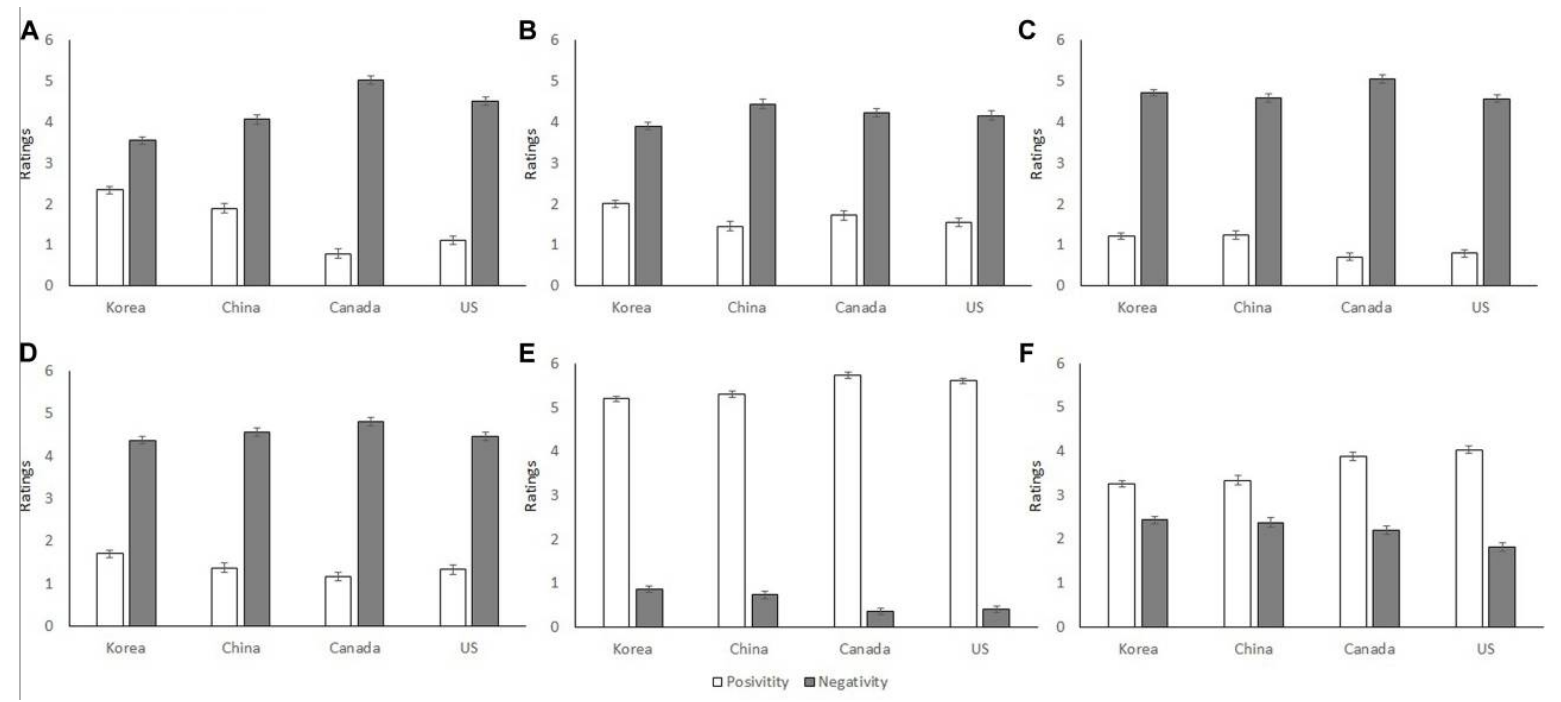

(A) Sadness, (B) Fear, (C) Disgust, (D) Anger, (E) Happiness, (F) Surprise. (0=Not at all; $6=$ Extremely).

Figure 2. Positivity and Negativity of Emotions Across Countries

In Figure 2, it is also seen that positive meaning of fear, which is a stronger reflection of apprehension, is stronger when compared to other emotions with negative meaning. In other words, apprehension may be discussed as both a positive and negative emotion. Apprehension is an emotion which causes that the individual feels anxious about the incidents that he cannot anticipate and predict. Positive features of apprehension can be explained by the fact that the individual is stimulated against the situation that causes apprehension and it enables the individual to take precautions, it leads the individual to happiness and success and contributes in personality development of the individual; negative features of apprehension can be explained by the fact that the individual damages his emotional life, gets depressed and is taken by fear by having unreasonable thoughts (Akgün, Gönen, \& Aydın, 2007). When the individual encounters a situation which makes him unhappy or he cannot anticipate and control, he feels insufficient and have unreasonable thoughts (Nelson, 2007). This situation which is the basic cause of apprehension is caused by the inconsistency between the individual's skills and apprehensions. This inconsistency affects efficiency and effectiveness of the individuals.

All individuals are under the influence of positive and negative emotions which may occur in different ways in relation to same incidents and people. Many university students are trying to cope with anxiety which have both positive and negative features. The results of the research conducted by University of Pennsylvania Center for 
Mental Health with the participation of over 100.000 students exhibit that more than half of the students who apply to mental health clinics are diagnosed with high anxiety levels (Penn's Center for Collegiate Mental Health, 2015). The American College Health Association (ACHA) reported that one out of 6 university students have high anxiety level in a report they published (American College Health Association, 2015). In addition, other researches exhibited the relationships between the anxiety level of the university students and their attitudes towards teaching profession (Doğan \& Çoban, 2009), studying attitudes and habits (Aydın, 1990) and commitment styles (Demir, 2017).

In Turkey, it is thought that preservice teachers' obligation to take Public Personnel Selection Examination and then the interview, insufficient number of open positions, that some departments are too crowded and the unemployment problem which will occur due to the failure and not being able to be appointed based on these factors, also the feeling of individual, professional, economic and social inadequacy would cause professional anxiety in preservice teachers. This anxiety state might affect various positive emptions and cause that oppression, depression and fear emotions are dominant among students. For that reason, exhibiting the relationship between anxiety and positive emotions is considered important as it will raise awareness about removing the barriers in front of preservice teachers' having positive perspective as a result of positive emotions. For that reason, this study aims to determine the predictive role of professional anxiety levels of education faculty students on positive emotions. In that respect, answers are sought for the following questions:

1. What are the professional anxiety levels of preservice teachers?

2. What are the positive emotion levels of preservice teachers?

3. Is there a significant relationship between the professional anxiety levels and positive emotion levels of preservice teachers?

4. Are professional anxiety levels of preservice teachers a significant predictor of their positive emotion levels?

\section{Method}

\subsection{Research Model}

In this study which investigates the predictive role professional anxiety levels of preservice teachers on positive emotions, relational screening model, which aims to determine the existence or extent of covariance between two or more variables (Karasar, 2005) is used.

\subsection{Population and Sample}

Population of this research consists of 2439 preservice teachers studying at Kırıkkale University Education Faculty; the sample of the research consists of 484 preservice teachers chosen by stratified sampling. Distribution of the sample according to departments is given in Table 1 and distribution according to grades is given in Table 2:

Table 1. Distribution of Sample Chosen by Stratified Sampling Method According to Departments

\begin{tabular}{llcc}
\hline Department & Population & Percent & Sample \\
\hline Computer And Instructional Technologies T. & $219+2$ & $9.06 \%$ & 37 \\
Science Teaching & $361+12$ & $15.29 \%$ & 62 \\
Primary School Mathematics Teaching & 80 & $3.28 \%$ & 13 \\
Preschool Teaching & 243 & $9.96 \%$ & 40 \\
Psychological Counselling And Guidance & $300+316$ & $25.25 \%$ & 101 \\
Primary School Teaching & $407+9$ & $17.05 \%$ & 69 \\
Social Sciences Teaching & 220 & $9.02 \%$ & 37 \\
Turkish Teaching & $267+3$ & $11.07 \%$ & 45 \\
TOTAL & 2439 & $99.98 \%$ & 484 \\
\hline
\end{tabular}


Table 2. Distribution of Sample Chosen by Stratified Sampling Method According to Grades

\begin{tabular}{|c|c|c|c|c|c|c|c|c|c|}
\hline \multirow{2}{*}{ Department } & \multicolumn{2}{|c|}{$1^{\text {st }}$ Class } & \multicolumn{2}{|c|}{$2^{\text {st }}$ Class } & \multicolumn{2}{|c|}{$3^{\text {st }}$ Class } & \multicolumn{2}{|c|}{$4^{\text {st }}$ Class } & \multirow[t]{2}{*}{ Total } \\
\hline & $\%$ & $\mathrm{n}$ & $\%$ & $\mathrm{n}$ & $\%$ & $\mathrm{n}$ & $\%$ & $\mathrm{n}$ & \\
\hline CIT Teaching & 1 & 1 & 26 & 10 & 25 & 9 & 48 & 17 & 37 \\
\hline Science Teaching & 16 & 10 & 23 & 14 & 23 & 14 & 39 & 24 & 62 \\
\hline P. S. Mathematics Teaching & 48 & 6 & 52 & 7 & - & - & - & - & 13 \\
\hline Preschool Teaching & 26 & 10 & 25 & 10 & 27 & 11 & 22 & 9 & 40 \\
\hline PCG & 28 & 28 & 30 & 31 & 22 & 22 & 20 & 20 & 101 \\
\hline Primary School Teaching & 21 & 15 & 21 & 14 & 26 & 18 & 32 & 22 & 69 \\
\hline Social Sciences Teaching & 24 & 9 & 24 & 9 & 29 & 11 & 23 & 8 & 37 \\
\hline Turkish Teaching & 22 & 10 & 24 & 11 & 23 & 10 & 31 & 14 & 45 \\
\hline
\end{tabular}

\subsection{Data Collection Tools}

For collecting the data required for the research, two instruments were used on preservice teachers. These are; Occupational Anxiety Scale developed by Cabı and Yalçınalp (2013) and Dispositional Positive Emotion Scale developed by Akın, Akın, Turan and Altundağ (2014).

Occupational Anxiety Scale consists of eight dimensions as Job Oriented Anxiety, Socio-Economic Centered Anxiety, Interaction with Students Centered Anxiety, Colleagues and Students' Parents Centered Anxiety, Self-Development Centered Anxiety, Occupational Exam Centered Anxiety, Adaptation Centered Anxiety and School Management Centered Anxiety and 45 items. In validity-reliability analyses conducted by Cabı and Yalçınalp (2013), the factor loads of the items in the scale vary between .50 and .90 , item correlation coefficients vary between .23 and .71 and Cronbach's Alpha reliability coefficients of sub-dimensions vary between .67 and .90 . In the validity-reliability analyses conducted in this study, the factor loads of items vary between .30 and .70 , item correlation coefficients vary between .21 and .71 and Cronbach's Alpha reliability coefficients of sub-dimensions vary between .71 and .93 .

Dispositional Positive Emotion Scale consists of seven dimensions as joy, contentment, pride, love, compassion, amusement and aw and 38 items. In validity-reliability analyses conducted by Akin et al. (2014), correlation coefficients of the items in the scale vary between .18 and .68 and Cronbach's Alpha reliability coefficients of sub-dimensions vary between .75 and .92 . In the validity-reliability analyses conducted in this study, the factor loads of items vary between .30 and .69 , item correlation coefficients vary between .14 and .70 and Cronbach's Alpha reliability coefficients of sub-dimensions vary between .77 and .87 .

\subsection{Data Analysis}

The data obtained from the scales was tested with SPSS 20 software package. In this research, preservice teachers' occupational anxiety and positive emotion levels are exhibited with arithmetic average; the relationships between their occupational anxiety and positive emotion levels are exhibited with correlation analysis and the predictive role of preservice teachers' occupational anxiety levels on their positive emotion levels are exhibited with regression analysis.

\section{Results}

In this section, results are given in subtitles according to research questions. Average and standard deviation values about occupational anxiety and positive emotion levels of the preservice teachers are included in the first part of this section; results on relationships between occupational anxiety and positive emotion levels of the preservice teachers are included in the second part of this section and then the results on the predictive role of occupational anxiety levels of preservice teachers on their positive emotion levels are included.

\subsection{Average and Standard Deviation Values about Variables}

Average and standard deviation values of variables are given in Table 3: 
Table 3. Average and Standard Deviation Values of Variables

\begin{tabular}{|c|c|c|c|c|}
\hline & Variables & $\mathrm{n}$ & $\bar{X}$ & S \\
\hline \multirow{8}{*}{ 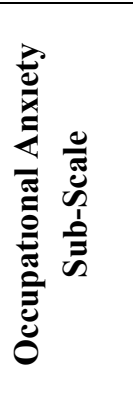 } & Job Oriented Anxiety & 484 & 3.56 & .90 \\
\hline & Socio-Economic Centered Anxiety & 484 & 3.58 & .90 \\
\hline & Interaction with Students Centered Anxiety & 484 & 3.43 & 1.06 \\
\hline & Colleagues and Students' Parents Centered Anxiety & 484 & 3.26 & .88 \\
\hline & Self-Development Centered Anxiety & 484 & 3.44 & 1.12 \\
\hline & Occupational Exam Centered Anxiety & 484 & 3.61 & 1.2 \\
\hline & Adaptation Centered Anxiety & 484 & 3.31 & 1.11 \\
\hline & School Management Centered Anxiety & 484 & 4.42 & .96 \\
\hline \multirow{7}{*}{ 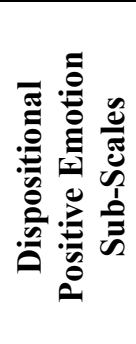 } & Joy & 484 & 4.48 & 1.14 \\
\hline & Contentment & 484 & 4.32 & 1.23 \\
\hline & Pride & 484 & 5.14 & 1.02 \\
\hline & Love & 484 & 4.49 & 1.16 \\
\hline & Compassion & 484 & 5.43 & 1.1 \\
\hline & Amusement & 484 & 4.99 & 1.12 \\
\hline & Awe & 484 & 4.68 & .99 \\
\hline
\end{tabular}

When Table 3 is examined, the variable with the highest average in occupational anxiety dimension is Occupational Exam Centered Anxiety $(X=3.61)$ and the variable with the lowest average is Colleagues and Students' Parents Centered Anxiety $(\bar{X}=3.26)$ in the occupational anxiety dimension; the variable with the highest average is compassion $(\bar{X}=5.43)$ and the variable with the lowest average is contentment $(\bar{X}=4.32)$ in the positive emotion dimension.

\subsection{Relationships Between Occupational Anxiety and Positive Emotion Levels of Preservice Teachers}

Results obtained as a result of the correlation analysis conducted for determining the relationships between the occupational anxiety and positive emotion levels of the preservice teachers are given in Table 4:

Table 4. Relationships between the Occupational Anxiety and Positive Emotion Levels of the Preservice Teachers

\begin{tabular}{|c|c|c|c|c|c|c|c|c|c|c|c|c|c|c|c|c|c|}
\hline Variables & 1 & 2 & 3 & 4 & 5 & 6 & 7 & 8 & 9 & 10 & 11 & 12 & 13 & 14 & 15 & 16 & 17 \\
\hline 1. Job Oriented A. & 1 & $.53 * *$ & $.77 * *$ & $.67 * *$ & $.69^{* *}$ & $.37 * *$ & $.50 * *$ & $.56^{* *}$ & $-.31 *$ & $-.38 * *$ & $-.26^{* *}$ & $-.13 * *$ & $\begin{array}{c}-.11 * \\
*\end{array}$ & $-.21 * *$ & $-.15^{* *}$ & & \\
\hline 2.Socio-Economic Centered A. & & 1 & $.51 * *$ & $.60^{* *}$ & $.60^{* *}$ & $.46^{* *}$ & $.68^{* *}$ & $.60^{* *}$ & $-.20 * *$ & $-.48^{* *}$ & $-.16^{* *}$ & $-.25 * *$ & $-.02 *$ & $-.16 * *$ & $-.17 * *$ & & \\
\hline 3. Interaction with St. C. A. & & & 1 & $.59 * *$ & $.64 * *$ & $.42 * *$ & $.42 * *$ & $.51 * *$ & $-.07 *$ & $-.09 *$ & $-.21 * *$ & $-.11 * *$ & $-.06^{*}$ & $-.11^{*}$ & $-.11 *$ & & \\
\hline 4. Colleagues/St.s' Parents C. A. & & & & 1 & $.58^{* *}$ & $.33 * *$ & $.49 * *$ & $.78^{* *}$ & $-.14 * *$ & $-.22 * *$ & $-.24 * *$ & $-.17 * *$ & $-.09 *$ & $-.23 * *$ & $-.14 * *$ & & \\
\hline 5. Self-Development C. A. & & & & & 1 & $.36 * *$ & $.45^{* *}$ & $.51 * *$ & $-.09 *$ & $-.16^{* *}$ & $-.20 * *$ & $-.11^{*}$ & $-.04 *$ & $-.14 * *$ & $-.08^{*}$ & & \\
\hline 6. Occupational Exam C. A. & & & & & & 1 & $.48^{* *}$ & $.35^{* *}$ & $-.29 * *$ & $-.55^{* *}$ & $-.13^{* *}$ & $-.16^{* *}$ & $-.04 *$ & $-.08^{*}$ & $-.10^{*}$ & & \\
\hline 7. Adaptation Centered Anxiety & & & & & & & 1 & $.45^{* *}$ & $-.20 * *$ & $-.27 * *$ & $-.20 * *$ & $-.24 * *$ & $-.11 *$ & $-.23 * *$ & $-.19 * *$ & & \\
\hline 8. School Management C. A. & & & & & & & & 1 & $-.13^{* *}$ & $-.17^{* *}$ & $-.13 * *$ & $-.15 * *$ & $-.03 *$ & $-.17 * *$ & $-.12 *$ & & \\
\hline 9.Joy & & & & & & & & & 1 & $.77 * *$ & $.54 * *$ & $.56^{* *}$ & $.40^{* *}$ & $.45^{* *}$ & $.48^{* *}$ & & \\
\hline 10.Contentment & & & & & & & & & & 1 & $.55^{* *}$ & $.52 * *$ & $.41^{* *}$ & $.43^{* *}$ & $.47 * *$ & & \\
\hline 11.Pride & & & & & & & & & & & 1 & $.37 * *$ & $.62^{* *}$ & $.50^{* *}$ & $.52 * *$ & & \\
\hline 12.Love & & & & & & & & & & & & 1 & $.39^{* *}$ & $.41^{* *}$ & $.49^{* *}$ & & \\
\hline 13.Compassion & & & & & & & & & & & & & 1 & $.53 * *$ & $.53^{* *}$ & & \\
\hline 14.Amusement & & & & & & & & & & & & & & 1 & $.52 * *$ & & \\
\hline 15.Awe & & & & & & & & & & & & & & & 1 & & \\
\hline 16. Occupational Anxiety Tot. & & & & & & & & & & & & & & & & 1 & $.27^{* *}$ \\
\hline 17. D. Positive Emotion Tot. & & & & & & & & & & & & & & & & & 1 \\
\hline
\end{tabular}

$* * p<.01 ; * p<.05$ 
When Table 4 is examined, the highest relations between the occupational anxiety and positive emotion levels of preservice teachers are between contentment and Occupational Exam Centered Anxiety $(r=-.55 ; p<.01)$ and Socio-Economic Centered Anxiety $(r=-.48 ; p<.01)$. In addition, there are also high-level relationships between Colleagues and Students' Parents Centered Anxiety and School Management Centered Anxiety $(r=.78 ; p<.01)$ and between joy and contentment $(r=.77 ; p<.01)$. On the other hand, the weakest relations are between compassion and Socio-Economic Centered Anxiety $(r=-.02 ; p<.05)$ and School Management Centered Anxiety $(r=-.03 ; p<.05)$. Also, there are weak relationships between Colleagues and Students' Parents Centered Anxiety and Occupational Exam Centered Anxiety $(r=.33 ; p<.01)$ and between pride and love $(r=.37 ; p<.01)$.

\subsection{Results on Occupational Anxiety of Preservice Teachers Predicting Positive Emotions}

In accordance with the "Are professional anxiety levels of preservice teachers a significant predictor of their positive emotion levels?" sub-problem of the research, results of the multiple regression analysis in relation to Job Oriented Anxiety, Socio-Economic Centered Anxiety, Interaction with Students Centered Anxiety, Colleagues and Students' Parents Centered Anxiety, Self-Development Centered Anxiety, Occupational Exam Centered Anxiety, Adaptation Centered Anxiety and School Management Centered Anxiety levels predicting the positive emotion levels are given in Table 5.

Table 5. Multiple Regression Analysis Results about Anxiety Sub-Dimensions Predicting Positive Emotions

\begin{tabular}{|c|c|c|c|c|c|}
\hline Variables & $\mathrm{B}$ & $S E$ & $\beta$ & $\mathrm{t}$ & $p$ \\
\hline Constant & -3.70 & .19 & & 19.50 & .00 \\
\hline Job Oriented Anxiety & -.15 & .08 & -.17 & -1.88 & .06 \\
\hline Socio-Economic Centered Anxiety & -.10 & .07 & -.21 & -1.42 & .00 \\
\hline Interaction with Students Centered Anxiety & -.08 & .06 & -.11 & -1.40 & .16 \\
\hline Colleagues and Students' Parents Centered Anxiety & -.16 & .08 & -.18 & -2.00 & .15 \\
\hline Self-Development Centered Anxiety & -.06 & .05 & -.08 & -1.11 & .26 \\
\hline Occupational Exam Centered Anxiety & -.28 & .04 & -.34 & -.70 & .01 \\
\hline Adaptation Centered Anxiety & -.10 & .05 & -.14 & -2.05 & .48 \\
\hline School Management Centered Anxiety & -.09 & .07 & -.09 & -1.31 & .19 \\
\hline
\end{tabular}

$\begin{array}{lrl}R & =.33 & R^{2}=.11 \\ F & =5.878 & p<.01\end{array}$

When Table 5 is examined, Job Oriented Anxiety, Socio-Economic Centered Anxiety, Interaction with Students Centered Anxiety, Colleagues and Students' Parents Centered Anxiety, Self-Development Centered Anxiety, Occupational Exam Centered Anxiety, Adaptation Centered Anxiety and School Management Centered Anxiety variables together give low and significant relationship with positive emotions $\left(R=.33 ; R^{2}=.411 ; p<.01\right)$. The abovementioned eight variables explain $11 \%$ of total variance of positive emotion. According to standardized regression coefficient $(\beta)$, the order of importance of predictive variables on positive emotions of preservice teachers is Occupational Exam Centered Anxiety, Socio-Economic Centered Anxiety, Colleagues and Students' Parents Centered Anxiety, Job Oriented Anxiety, Adaptation Centered Anxiety, Interaction with Students Centered Anxiety, School Management Centered Anxiety and Self-Development Centered Anxiety. When the $t$-test results in relation to significance of regression coefficients are examined, it is seen that socio-economic centered anxiety and occupational exam centered anxiety are significant predictors of positive emotions. Job Oriented Anxiety, Interaction with Students Centered Anxiety, Colleagues and Students' Parents Centered Anxiety, Self-Development Centered Anxiety, Adaptation Centered Anxiety and School Management Centered Anxiety do not have significant impact on positive emotions of preservice teachers.

\section{Discussion}

In this research in which the predictive role of occupational anxiety levels of preservice teachers on positive emotions are determined, it was determined that the variable with the highest average in occupational anxiety dimension is occupational exam centered anxiety. In March 2018, Ministry of National Education has announced that they will appoint 20 thousand contracted teachers and 131.895 preservice teachers have applied for this announcement (Ministry of National Education, 2018). When the number of teachers to be appointed and the number of applicants is compared, it is seen that almost 6 out of 7 preservice teachers will not be appointed and will remain jobless. This causes that occupational exam centered anxiety is experienced more intensely among students. In 
addition, researches exhibited that senior students at the education faculty experience exam anxiety (Özsarı, 2008), education faculty students expressed their views that Public Personnel Selection Examination should be annulled and appointment system should change and they experience anxiety for not being able to be appointed as a result of the Public Personnel Selection Examination (Atav \& Sönmez, 2013). On the other hand, the variable with the lowest average is Colleagues and Students' Parents Centered Anxiety. This can be explained by the fact that preservice teachers experience occupational exam centered anxiety primarily and other anxiety types may become more intense after the occupational exam centered anxiety is overcome. On the other hand, the variable with the highest average in positive emotions dimension is compassion. Considering that preservice teachers spend their university years away from their families in general, it can be said that they need support of each other and for that reason they are more compassionate about each other. In their study conducted with university students, Atasay and Doğu (2017) exhibited that students mostly anticipate academic and then physical support from their friends. On the other hand, the fact that the variable with the lowest average is contentment can be explained by the fact that there are many problems about teaching profession and effective solutions cannot be found for these problems. Existence of such problems may cause that preservice teachers experience discomfort.

Another conclusion of this research is that there is a negative relationship between contentment and occupational exam centered anxiety and socio-economic centered anxiety. In other words, preservice teachers' anxiety towards appointment and socio-economic life affect their contentment levels negatively. In general, adults evaluate their lives within the framework of causes and they compare the features of their lives with the features of the life that they want to have. High compatibility level obtained as a result of this comparison, which means the fulfilment of individuals' expectations at a high rate, is the key to contentment (Rojas \&Veenhoven, 2013). It can be said that preservice teachers' anxiety towards the possibility that their expectations about appointment and socio-economic issues will not be fulfilled and that their wishes and what they will live will not match affect their contentment levels negatively.

In this research, it is also concluded that occupational exam centered anxiety and socio-economic centered anxiety are significant predictors of positive emotions. After completing their education, preservice teachers face Public Personnel Selection Examination and interview system during transition to teaching profession and majority of the preservice teachers cannot be appointed and remain jobless after these examination as mentioned above. This causes that occupational exam centered anxiety of preservice teachers is intensified primarily. Another anxiety caused by not being able to be appointed affects both economic and social lives of preservice teachers. A preservice teacher who graduated from university and who is not appointed may experience difficulties in relation to living on economically and may be obliged to work in different jobs which are not related to their education until they take the examination again. This obligation may trigger social anxiety of preservice teachers. In addition, due to the fact that the income that they will earn when they become teachers is at an amount to meet vital necessities, the idea of being socially weak may also cause social centered anxiety. Given that anxiety is closely related to hopelessness level (Sevinç \& Özdemir, 2017) and the perception that Public Personnel Selection Examiation damages social life and relationships and affect participation levels in artistic, cultural and sportive activities negatively (Sezgin \& Duran, 2011), preservice teachers' experiencing occupational exam and socio-economic centered anxiety may prevent that they live alive in which positive emotions are intense.

\section{Conclusion and Suggestions}

In this research in which the predictive role of occupational anxiety of preservice teachers on positive emotions are determined, the variable with the highest average is occupational exam centered anxiety in in occupational anxiety dimension and compassion in positive emotions dimension. In addition, it is determined that there is a negative relationship between contentment and occupational exam centered anxiety and socio-economic centered anxiety. Furthermore, it is also concluded that occupational exam centered anxiety and socio-economic centered anxiety are significant predictors of positive emotions.

Taking into consideration the negative predictive role of occupational exam centered anxiety of preservice teachers on positive emotions, it may be suggested that a quota restriction is introduced in departments where teacher appointments are limited, the transition of faculty of letters graduates to teaching is stopped and awareness programs are prepared which will offer different perspectives towards occupational life for students. On the other hand, it may also be suggested that improvements are made for teachers to have financial satisfaction for reducing their socio-economic centered anxiety which predicts their positive emotions negatively; payments for family, children, rent and similar needs are increased; an agreement similar to the one signed with the Ministry of National Education 
for making cinema tickets 8 Turkish Liras for teachers in weekdays is also signed in services such as theaters, domestic and overseas holidays and restaurants. In addition, it may also be suggested that researchers investigate factors which enables preservice teachers to experience positive emotions more intensely. Intensity of positive emotions may be guiding for ensuring that preservice teachers are less anxious individuals.

\section{References}

Akgün, A., Gönen, S., \& Aydın, M. (2007). İlköğretim fen ve matematik öğretmenliği öğrencilerinin kayg1 düzeylerinin bazı değişkenlere göre incelenmesi. Elektronik Sosyal Bilimler Dergisi, 6(20), 283-299.

Akın, A., Akın, Ü., Turan, M. E., \& Altundağ, Y. (2014). The validity and reliability of the Turkish version of the Dispositional Positive Emotion Scales. Procedia-Social and Behavioral Sciences, 152, 78-81. https://doi.org/10.1016/j.sbspro.2014.09.158

American College Health Association. (2015). 2015 National College Health Assessment Survey. Retrieved from https://www.acha.org/484.aspx?aspxerrorpath=/iMIS/484.aspx

An, S., Ji, L.-J., Marks, M., \& Zhang, Z. (2017). Two sides of emotion: Exploring Positivity and negativity in six basic emotions across cultures. Frontiers in Psychology, 8, 610. https://doi.org/10.3389/fpsyg.2017.00610

Atasay, I., \& Doğu, Ö. (2017). Sağlık yüksekokulu öğrencilerinde akran desteğinin önemi, J Hum Rhythm, 3, $62-67$.

Atav, E., \& Sönmez, S. (2013). Öğretmen adaylarının Kamu Personeli Seçme Sınavı'na ilişkin görüşleri. Hacettepe Üniversitesi Ë̆itim Fakültesi Dergisi, Özel Sayı, 1-13.

Aydın, B. (1990). Üniversite öğrencilerinin kaygı düzeyleri ile ders çalışma tutum ve alışkanlıklarının incelenmesi. Psikoloji Dergisi, 7(25), 33-40.

Cabı, E., \& Yalçınalp, S. (2013). Öğretmen Adaylarına Yönelik Mesleki Kaygı Ölçeği (MKÖ): Geçerlik ve güvenirlik çalışması. Hacettepe Üniversitesi Eğitim Fakültesi Dergisi, 44, 85-96.

Demir, S. (2017). Üniversite Öğrencilerinin bağlanma stilleri ile kaygı düzeyleri ve yetersizlik duyguları arasındaki ilişskinin incelenmesi. Yüksek Lisans Tezi, Beykent Üniversitesi Sosyal Bilimler Enstitüsü, İstanbul.

Doğan, T., \& Çoban, A. (2009). Eğitim fakültesi öğrencilerinin mesleğine yönelik tutumları ile kaygı düzeyleri arasındaki ilişkinin incelenmesi. Eğitim ve Bilim, 34(153), 157-168.

Freedman, J. (2007). At the heart of leadership: How to get results with emotional intelligence. San Mateo, CA: Six Seconds.

Frijda, N. H. (2008). The psychologists' point of view. In M. Lewis and J. M. Haviland (Eds.), Handbook of Emotions (pp. 68-101). New York: Guilford Press.

Gray, J. A. (1982). The Neuropsychology of anxiety. Oxford: Oxford University Press.

Karasar, N. (2005). Bilimsel araştırma ve yöntemi. Ankara: Nobel Yayın Dağıtım.

Kervanc1, F. (2008). Büro çalışanlarının duygu yönetimi yeterlilik düzeylerinin geliştirilmesinde duygu yönetimi eğitimi programının etkisi. Yüksek Lisans Tezi, Gazi Üniversitesi Eğitim Bilimleri Enstitüsü, Ankara.

Kleinginna, P. R., \& Kleinginna, A. (1981). Categorized list of emotion definitions, with suggestions for a consensual definition. Motivation and Emotion, 5, 345-379. https://doi.org/10.1007/BF00992553

Milli Eğitim Bakanlığı (2018). Sözleşmeli öğretmenliğe başvuru ve atama duyurusu. Retrieved from http://personel.meb.gov.tr/

Nelson, B. (2007). The emotion code: How to release your trapped emotions for abundant health, love and happiness. Nevada: Wellness Unmasked Publishing.

Oatley, K., \& Jenkins, J. (1996). Understanding emotions. Oxford: Blackwell.

Oatley, K., \& Johnson-Laird, P. N. (1987). Toward a cognitive theory of emotions. Cognition \& Emotion, 1, 29-50. https://doi.org/10.1080/02699938708408362

Özsarı, İ. (2008). Eğitim fakültesi son sinı öğrencilerinin KPSS merkezi sinavı odakl gelecek kaygıları ve mesleki beklentileri. Yüksek Lisans Tezi, İstanbul Üniversitesi Sosyal Bilimler Enstitüsü, İstanbul.

Penn's Center for Collegiate Mental Health (2015). Center for Collegiate Mental Health (CCMH) 2015 Annual Report. Retrieved from https://files.eric.ed.gov/fulltext/ED572760.pdf 
Plutchik, R. (1980). Emotion: A psychoevolutionary synthesis. New York: Harper \& Row.

Plutchik, R. (2001). That nature of emotions: human emotions have deep evolutionary roots, a fact that may explain their complexity and provide tools for clinical practice. Sigma Xi, The Scientific Research Society, 89(4), 344-350.

Rojas, M., \& Veenhoven, R. (2013). Contentment and affect in the estimation of happiness. Social Indicators Research, 110(2), 415-431. https://doi.org/10.1007/s11205-011-9952-0

Schachter, S., \& Singer, J. E. (1962). Cognitive, social, and physiological determinants of emotional state. Psychological Review, 69, 379-399. https://doi.org/10.1037/h0046234

Sevinç, S., \& Özdemir, S. (2017). Hemşirelik öğrencilerinin kaygı ve umutsuzluk ilişkisi: Kilis örneği. Hemşirelikte Araştırma Geliştirme Dergisi, 19(2), 14-24.

Sezgin, F., \& Duran, E. (2011). Kamu Personeli Seçme Sınavı'nın (KPSS) öğretmen adaylarının akademik ve sosyal yaşantılarına yansımaları. Türkiye Sosyal Araştırmalar Dergisi, 3, 9-22.

Tuna, Y. (2011). Duygular. In Sezen Ünlü (Ed.), Birey ve davranış, (pp. 20-40). Eskişehir: Anadolu Üniversitesi Yayınları. 